\title{
Fifth Geneva Lecture: A Competitive Insurance Market in the Former GDR - an Analysis of the Situation in Autumn 1990
}

\author{
by Prof. Dr. jur. Dr.-Ing. E.h. Reimer Schmidt*
}

\section{Introduction}

The unification of the German Democratic Republic - founded under the aegis of the USSR on the territory of the former Soviet zone of occupation - with the Federal Republic of Germany has brought with it a number of problems. This paper will deal essentially with the creation of an insurance market and with the transition from a monopolistic, centrallymanaged, planned economy based on State ownership to a market economy. The task involved is quite a daunting one. From the structure of its economy, it was clear the ideas of glasnost and perestroika had scarcely pentrated the GDR.

Consequently, little if any liberalisation of the insurance industry took place before the change - in strong contrast to the situation in Hungary and Poland, which were trailblazers in this respect. ${ }^{2}$

\section{Basic problems}

In 1986, 16,6 million people (compared with 14,8 million in Czechoslovakia and 13,8 million in the Netherlands) were living in an area of around 108,000 square kilometres (for comparison, Iceland covers an area of 103,000 square kilometres and Bulgaria 110,000). According to a survey carried out by the Swiss Rc, ${ }^{3}$ the volume of premiums in 1988 was

\footnotetext{
1 The manuscript was completed directly after the unification of the two Germanies, on 10th October 1990 . Hence it reflects the situation of that precise time. The footnotes contain German evidence material and are therefore given in German.

"Président d'Honneur de l'Association Internationale pour l'Etude de l'Economie de l'Assurance. Conference given at Castle Zeist. Netherlands on the 15th November 1990, organized with the contribution of the Munich Reinsurance Company and introduced by Dr. Hans Barfelds, chairman of the executive board, N. V. Amev, Utrecht (Holland).

${ }^{2}$ Dazu z. B. Handelsblatt vom 29. 8. 1990, S. 11. Markt.

3 Schweizer Rück, Sigma 5/90, Osteuropa: Schwieriger Weg vom Versicherungsmonopol zum
} 
around US $\$ 4$ billion, roughly $52 \%$ of this being accounted for by Life and roughly $48 \%$ by Non-Life business. Here it should be borne in mind that domestic premiums were low.

The economy was structured on the Soviet model of a centrally-planned economy organised on a kind of barter system where goods and services were treated on the basis of valuation units. The East German economy, as such, played a quite considerable role in the internal currency system of the Council for Mutual Economic Assistance (CMEA) - or Comecon, as it was then known. It was geared to complementing the Soviet economy but was at the same time more or less partly affiliated to the EEC, albeit confined to a "secondary circuit". Its character was particularly influenced by its substantial armaments industry, while, in line with its economic structure, its collectivised agriculture also played a considerable role. The political collapse of the GDR at the same time meant the collapse of its economy, especially since it naturally lacked the workable infrastructure needed for rapid adjustment. Economic factors were not the direct cause of the change, however.

I do not need to go into the reasons why the West regards German unification with a certain amount of apprehension. Such apprehension also exists in both parts of Germany, though for different reason. My presentation is therefore intended to provide you with facts and viewpoints as seen by a European considering both the technical and practical aspects of the problems facing the "insurance world". I hope to do this without arrogance and not in a "know all" attitude, but in a manner which enables you to form your own opinion.

It has to be assumed that the system in the GDR collapsed for political and psychological reasons. At this point I shall briefly mention only those specific psychological factors ${ }^{4}$ which have an effect on the creation of competitive markets, though obviously here it will only be possible to give brief indications and key words bearing a dialectical relationship to each other:

- There were certain influences of German idealism in the direction of socialist ideology, as was also the case with regard to the Jugendbewegung, the youth movement at the beginning of this century, for example. The disappointment caused by the reality of the socialist utopia therefore had a crippling effect.

- The image which people have of each other, and with it the basic socio-psychological situation, have been changed so much by twelve years of Nazi dictatorship and forty years of incorporation into the Soviet system that it will be very difficult to alter it in a short course of time, particularly as Christianity was very much pushed in the background.

- Account has to be taken of the "thinning" of the GDR's working population, particularly in the years immediately after the war, with the most energetic people, the bettereducated and the young emigrating to West Germany.

- In this connection, the "deployment" of people to work in a centrally-planned economy led the work factor to be viewed quite differently from the way it is in the free world. Overmanning in all types of jobs was more or less the norm, and the idea of "achieving targets" replaced that of performance to such an extent that the latter will not be easy to revive.

4 Aus dem umfangreichen Material ist der Leitartikel der Neuen Zürcher Zeitung vom 9./10. 9. 1990 "Hoffen und Bangen im anderen Deutschland" hervorzuheben. 
- The image of the Federal Republic presented by the East German media and party training, and also the opposing one presented by the West German media, continue to have an effect. The fact or idea that the GDR had "come off worse" as a result of the Second World War in turn gave rise to a certain tendency among Germans towards self-pity. At any rate, the loss of self-confidence which is to be found may lead to critical considerations.

- On the other hand, disappointed pride in one's own performance and exaggerated expectations of the market economy, along with the justified criticism of inadequate competitive behaviour, lead to feelings of displeasure, particularly since the "change" resulted from spontaneous impetus and less from considcred, planned action. Displeased reactions are also to be seen from so-called "intellectuals", who are losing their thoroughly serious "socially unjust" privileges, and from the enormous number of people who are now suffering disadvantages as a result of their activity for the Communist Party and/or the State security service - or "Stasi" - and these tend to have a negative effect as multipliers of public opinion.

- Certainly there is a big danger that the citizens of West Germany and Western Europe will assess the psychological situation too pessimistically, and it should be remembered that the many millions of East and Central Germans who came to West Germany in several waves after 1945 made substantial contribution to the development of our country and this economy. Why shouldn't their relatives who remained in the Eastern zone make as big a contribution there?

I have mentioned psychologically relevant aspects of this kind not because they represent my own personal assessment, but because they should enable anyone wanting to do business in the former GDR to "feel" themselves into the psychological situation.

You see, I do not share the critically negative assessment of the situation, nor am I affected by neo-patriotism. It should be borne in mind though that the time which has elapsed from the fall of Honecker (without bloodshed) to the accession on 3rd October was exactly fifty weeks, that stable and predictable constitutional and political conditions have been created, and that the hard-currency Deutsche Mark has been introduced. The coming winter will doubtlessly bring a few more difficulties; in the longer term, however, only through energy and not through pessimism will it be possible to overcome the psychological damage caused by dictatorship. And this is a challenge and a chance as well for the West.

\section{Procedure under national and international law}

Before going on to deal with the problems associated with the creation of a competitive insurance market, here in the neighbouring country of the Netherlands we have to give a broad outline of the special features of the GDR's unification with the Federal Republic. As you may known, the Grundgesetz (Basic Law) - the Constitution formally approved by the Western Allies - made provision for reunification "in peace and freedom", and thus represented, as it were, a standing offer to the other parts of Germany to join this parliamentary democracy. This offer was accepted for the GDR by the parliament formed aftcr free elections and the government which ensued, in a proper procedure under both national and international law ${ }^{5}$ which also took account of the Allies' rcscrvations.

${ }^{5}$ Dazu z. B. Horn, Völkerrechtliche Aspekte der deutschen Vereinigung, Neue Juristische Wochenschrift 1990, S. 2173; vgl. auch W. Heintschel v. Heinegg in Beilage 23 zu BB 1990 Heft 23 , S. 9. 
The unification process was put into concrete terms by two International Treaties ${ }^{6}$ with their Annexes containing a large number of detailed arrangements. The second International Treaty, known as the "Unification Treaty", made it clear that the conditions for reunification were fulfilled, so that other parts of the former German Reich no longer come under it. This means that the cession of areas lost to the USSR and Poland following the Second World War is also voluntarily acknowledged. The political and legal difficulties of the whole process and the financial burdens involved can only be hinted at. The path taken was possible only because it was fully clear right from the outset that the whole process was to take place within the context of a wider European objective and therefore eased a set of problems which might otherwise have become acute after one or two generations.

During the period from November 1989 to accession, the GDR set up a considerable body of transitional law which can only be mentined in passing. ${ }^{7}$

\section{Survey of individual concrete steps (creation of an adequate general framework)}

The regulatory machinery created as a framework - which is perhaps better described as a "reversing arrangement" in the direction of a free system of government and economic order - serves amongst other things to create the necessary infrastructure for an insurance industry run along free-market lines. This means a complete change of the socioadministrative structure with regard to administration, jurisdiction, currency and credit system, and above all returning the legal norms of collectivism to individual rights in a socially harmonised and appropriate way. The arrangements relating to the "Currency Reform Compensation Fund" and to the preparation of balance sheets have not yet been concluded; these naturally are of quite considerable economic importance. ${ }^{8}$

Because of the need to consider the interests of those dispossessed - and frequently their heirs - and to look at the interests of the generation now in possession of expropriated assets, while at the same time bearing fairly in mind the basic right of private ownership, dealing with expropriations of land and businesses is fraught with problems, especially on account of the way that the law relating to mortgages is organized, and also with regard to the banking and insurance industry. As you may know, expropriations in the GDR took place in several "waves": thus expropriations resulting from the land reform carried out over the period 1945 to 1948 have a quite different history and give rise to quite different

6 "Zum Staatsvertrag über die Schaffung einer Währungs-, Wirtschafts- und Sozialunion (erster Staatsvertrag) vom 18. 05. 1990 (BGBI II S. 537: Entwurf eines Gesetzes zu dem Vertrag mit amtl. Begründung BT-Drucks. 11/7171, Art. 8 (Änderung des Versicherungsaufsichtsgesetzes), Begr. S. $28 \mathrm{f}$., Leitsatz B. I1.4. Abschaffung des Versicherungsmonopols, S. 66, Anlage V: Vorzunehmende Änderungen am Versicherungsaufsichtsgesetz, S. 89. Staatsvertrag vgl. z. B. EG-Informationen Nr. 14/1990; Rupert Scholz in BB a. a. O., S. 1 ff.

Zum Vertrag über die Herstellung der Einheit Deutschlands (Einigungsvertrag, zweiter Staatsvertrag vom 23. 04. 1990 BGBI II S. 885, BT-Drucks. 11/9960, z. B. abgedruckt in Die Welt vom 31.08. 1990, S. 5-8, Erläuterungen zu den Anlagen zum Einigungsvertrag BT-Drucks. 11/7817). Hinweise: Verzahnung mit dem EG-Recht Präambel Abs. 5 und Art. 10, Treuhandvermögen Art. 25, dazu Art. 4l, sowie in den wichtigen Anlagen: Anl. 1 Kap. III D, III, Nr. 8 K-Versicherung, Anl. 2 Kap. III B., I, Nr. 2 Fortgeltendes Recht, D I DM-Eröffnungsbilanz und Kapitalneufestsetzung (insbes. \$\$ 44-46 des dort genannten Gesetzes; dazu z. B. Dornberger-Dornberger in Der Betrieb DDR-Report S. 3122.

7 Über die am 01. 07. 1990 in Kraft getretenen Bundesgesetze Deutler, in BAnz 1990 Nr. 141a S. 3.

${ }^{8}$ Vgl. dazu z. B. Frankfurter Allgem. Zeitung vom 07. 09. 1990, S. 15. 
solution requirements from those with respect to the expropriation of companies (nationalisation $)^{9}$ and finally the expropriation/trusteeship of land belonging to refugees. According to the East German Registration Ordinance of 11. 07. 90, insurance companies whose assets in the GDR had been expropriated had to register their claims for restitution by 31st October, but only insofar as the expropriations were not based on occupation law. The assets of private insurers, however, had in any case already been confiscated in 1945 by the so-called "Zhukow Order" and an official announcement of the Soviet administration made on 04. 08. 1945. ${ }^{10}$ As to insurance companies having their head offices in what were then the Western zones, old mortgages which they had in respect of property in the GDR had also been expropriated - at any rate de facto - before the key date of 18 August 1948. ${ }^{11}$

With that, we have already touched on the subject of changing over from a monopoly system of insurance to a competitive system. The methods for achieving this changeover are particularly important. Just to remind you: up until the change, besides the Staatliche Versicherung der DDR (State Insurance Company of the GDR) - a monopoly institution with the obligation to insure - there was also the Deutsche Auslands- und Rückversicherungs-AG (German Foreign lnsurance and Reinsurance Company), or DARAG for short, operating as a joint-stock company owned by the State. ${ }^{12}$

Professor Wolfgang Zschockelt of the Humboldt University in East Berlin recently lectured in Vienna to a working party from the Geneva Association, ${ }^{13}$ contrasting the old order in the insurance industry with the one aimed for (naturally with critical comments) and at the same time explaining the insurance situation in the GDR: from the point of view of rational business management, the insurance monopoly forming one of the basic dogmas of all socialist planned economies had had definite advantages, namely large portfolios and no costs due to competition, with lower risk premiums as a result. Thus in the GDR the amount of premium per insurance employee was DM 0.58 million, while the corresponding amount in the Federal Republic was DM 0.6 million.

In the GDR, however, one insurance employee had to service an average of 1277 people while in the Federal Republic the figure was 250. The low cost-unit rate of the monopoly institution was attributable to, amongst other things, low salaries $(85 \%$ of the employees were women), antiquated technical equipment and poorer quality service. Zschockelt also mentioned the absence of any competitive pressure with respect to product innovation, premiums and service, and in particular the high level of profits transferred to the national budget.

${ }^{9} \mathrm{Zu}$ den Funktionen der "Treuhandanstalt" Einigungsvertrag Art. 25; vgl. auch Handelsblatt, Entschädigung statt Rückübertragung in volkswirtschaftlich wichtigen Fällen, Handelsblatt vom 29. 08. 1990, S. 6 .

${ }^{10}$ R. Schmidt, Die Neuordnung des Versicherungswesens in der sowj. Besatzungszone Deutschlands, ungedr. Diss. Hamburg 1948, S. 16-19; H. Möller, unter demselben Titel, Hamburg 1948, S. 10.

11 Erste Anordnung über die Behandlung von Forderungen von Kreditinstituten gegen Schuldner in der sowj. Besatzungszone Deutschlands vom 18.08. 1948.

12 Material bei R. Schmidt in Prölls-Schmidt-Frey Versicherungsaufsichtsgesetz, 10. Aufl., 1989, Vorbem. 100 und Vor 105 Rdnr. 8.

13 Vgl. Wolfgang Zschockelt, Probleme und Perspektiven des Versicherungsmarktes der DDR auf dem Weg zu einem gesamtdeutschen Versicherungsmarkt, in Entwicklung und Perspektiven des Versicherungswesen in der DDR, Schriftenreihe Versicherungsforum Heft 5, 1990, S. 43-69. 
With this changeover, questions of company structure, laws relating to competition and cartels and the law governing the banking industry are the main issues to come to the fore. Because, in the economic structure to be created, the insurance industry is not only an independent branch of the economy but also an auxiliary sector of other economic activities and, in particular, since - socially - Life, Sickness and Accident insurance represent an extremely important means of voluntary provision for the future, the industry's status under the law relating to competition is intimately bound up with the free-market organisation of the rest of the economy and with a constitutionally social system.

\section{Special importance of EC law}

The (first) International Treaty between the two German states already stipulates in its Preamble that the application of EC law is to be guaranteed after unification. Because, constitutionally, the GDR "acceeded" to the Federal Republic, it "jumped" as it were onto the moving train of EC law implementation, at the same time acknowledging that considerable advantages had accrued to it in the past from the workings of the EC. Stipulations made in the International Treaties mean that the policy of the GDR will be geared to the law of the European Comunities and in fact to the current dynamic process of creating a single European market into which the GDR will be "fitted", as it were. This situation has meant that it has not been necessary to have special transitional provisions as regards insurance - unlike when other states have acceeded to the EC. The fact that only the two state insurance companies already mentioned were in operation in the former GDR will certainly have played a part here. ${ }^{14}$

According to Article 10 of the Unification Treaty (second International Treaty), the entire system of European Community treaties in the versions currently applicable enter into force in the former GDR immediately when its accession becomes effective (paragraph 1). Legal instruments issued on the basis of EC law apply insofar as the competent bodies of the EC do not make provision for exemptions. Any instruments are supposed to "take account of administrative needs and serve to avoid economic problems" (paragraph 2).

\section{Questions of competition and, in particular, monopolies}

Irrespective of any EC exemption provisions, the Federal Republic's Law against Restraints of Competition (Cartel Law) already applies by virtue of what is known as the GDR Framework Law" (Law on the Implementation of the Legislation of the Federal

\footnotetext{
${ }^{14}$ Der Europäische Rat hatte am 28. 04. 1990 die Vereinigung Deutschlands "vorbehaltslos" begrüßt, das Europäische Parlament dies in seiner Entschließung vom 17.05. 1990 bestätigt. Dort hat insbes. der "nicht-ständige Ausschuß für die deutsche Vereinigung" auf Grund seiner Untersuchungen einen Zwischenbericht erstellt, der zu der Entschließung des EP vom 12. 07. 1990 geführt hat. Die Kommission hat sodann bereits am 21. 08. 1990 ein Vorschlagspaket in Gestalt des dreibändigen Dokuments (Kom. (90)400) endg.) verabschiedet (BR-Drucks. 580/90). Die deutschen Versicherungsaufsichtsbehörden hätten - so wird zum Bereich Finanzdienstleistungen/Versicherungen (Bd. I, Teil II, S. 68) ausgeführt, mitgeteilt. daß mit dem Beitritt das (EG-bestimmte) Aufsichtsrecht auf dem Gebiet der DDR ebenso angewendet werde wie in der Bundesrepublik. Besondere, die Versicherung betreffende Übergangsvorsehriften sind daher nicht ergangen. - Aus der Fülle des Materials ist auf die in der NJW, in der in demselben Verlag seit April 1990 erscheinenden Deutsch-Deutschen Rechtszeitschrift und in der Beilage "DDR-Rechtsentwicklungen" des BB zum Thema erschienenen Veröffentlichungen hinzuweisen.
} 
Republic of Germany of 21.06.1990, effective since 01.07. 1990), so that the basic principles of cartel law are established. ${ }^{15}$ The EC Commission made express reference to observation of these principles.

Even if the Federal Constitutional Court of the Federal Republic approved ${ }^{16}$ the constitutionality of the old, traditional kind of Buildings Fire insurance and not the kind provided by compulsory and monopoly institutions based on the ideas of "true socialism", and even if Article 4 of the First Coordinating Directive on Non-Life Insurance makes provision for these insurance institutions to be exempted from the freedom of establishment, ${ }^{17}$ the freedom of services which is about to be realised has still initiated a critical review of these institutions too. ${ }^{18}$ Monopoly rights make it impossible to establish business in the areas covered by the monopoly and would in any case mean discrimination in the area of freedom of services, which is currently undergoing rapid development. The compulsory insurances associated with monopoly insurance companies will also be regulated in connection with the final third Directive on Non-Life and Life Insurance, under which the consideration of welfare-state interests will carry weight and give rise to problems. ${ }^{19}$

The monopoly of the State Insurance Institution of the GDR was first of all weakened from the beginning of the year ${ }^{20}$ and then abolished by the first International Treaty, as were the quite numerous compulsory insurances, with the exception of Motor Liability. The acquisition by the Allianz of a share of more than $50 \%$ in the Deutsche VersicherungsAktiengesellschaft in East Berlin as a joint venture with the state insurance company renamed the Deutsche Versicherungsanstalt (or "German Insurance Institution") has been criticised from the point of view of cartel law, but not been objected to by the Federal Cartel Office. The factors playing a part here were, on the one hand, the desire to preserve jobs and avert the collapse of the state institution so as to safeguard the interests of the insured and, on the other, the idea of simultaneously ending the monopoly and opening up the market. Certainly, the new competitive insurers coming into the market are already supposed to have recruited a not insubstantial number of the former state insurance

15 Dazu die Übersicht über "Die von der DDR übernommenen Bundesgesetze mit den Anpassungs- und Überleitungsvorschriften" in Der Betrieb Nr. 8 vom 24. 08. 1990 S. 3094-3097.

16 BVerfG vom 14.01. 1976 NJW S. 667 (vorher bereits BVerfG vom 27. 10. 1959 Bd. 10, S. 141).

17 Richtl. 73/239/EWG, Amtsbl. L 228 vom 16. 08. 1973.

18 Dazu vor allem W.-H. Roth, Versicherungsmonopole und EWG-Vertrag, in Festschrift für Ernst Steindorff, Berlin, New York 1990, S. 1313-1332; zu dem sehr umfangreichen Schrifttum zur Dienstleistungsfreiheit zuletzt ders., Grundlagen des gemeinsamen Versicherungsmarktes, RabclsZ 1990 S. $63 \mathrm{ff} ., 87 \mathrm{ff}$.

19 Über die in erheblichem Umfang tnit Pflicht- und Monopolrechten ausgestatteten kantonalschweizerischen öffentlich-rechtlichen Feuerversicherungsanstalten der Kantone hat man übrigens bei Moritz Kuhn, Versicherungsrecht, in Schindler, Hertig u.a., Die Europaverträglichkeit des schweizerischen Rechts, Zürich 1990, S. 460 ff., im Zusammenhang mit dem zwischen der Schweiz und der EG geschlossenen niederlassungsrechtlichen Abkommen für die Nichtlebensversicherung nichts lesen können. In der Diskussion zieht man sich übrigelns teilweise auf die Wortinterpretation des Art. 4l, Koord. Richtl. Nichtlcben zurück, indem man in der Vorschrift nur eine Ausnahme bezüglich der aktiven Niederlassungsfreiheit erblickt.

${ }^{20}$ Verfassungsänderung vom 12.01. 1990 (DDR GB1. vom 30. 01. 1990), "Außerkraftsetzung", des Statuts zum 01. 05. 1990. 
institution's field staff. ${ }^{21}$ Incidentially, the rather gencrous way in which anti cartel law has been handled in this case by the Cartel Office, which is no doubt justified in the period of transition, is sure to be tightened up later on.

\section{Uniform insurance supervisory law}

It was first of all necessary to eliminate the discrepancy in company structures constituted by the fact that both German and foreign insurance companies operate in the Federal Rcpublic, while only two state organisations were to be found in the GDR. ${ }^{22}$ The powers of the BAV (the Federal Supervisory Office for Insurance) had therefore already bcen extended to the territory of the GDR, including East Berlin, with effect from 1st July 1990, it being stipulated that the BAV would have to take the interests of the GDR into account in any decisions ${ }^{23}$ and consult the GDR's Finance Minister in connection with any licences granted. In the first International Treaty a uniform German insurance supcrvisory law was then crcated. This involved calling upon what was still a "foreign" authority to carry out administration tasks - a happy solution as far as the subject matter was concerned. A new Section entitled "Transitional provisions for Implementation of the Monetary, Economic and Social Union with the GDR" was inserted into the Insurance Supervisory Law (VAG). ${ }^{24}$ These transitional provisions were then incorporated into the VAG (Articles 161-166) by law of 25. 06. 1990, ${ }^{25}$ being applicable until 3rd October. ${ }^{25 a}$ Through the developments taking place in national policy, the Insurance Supervisory Authority found itself in a situation in which, on the one hand, it had to prepare for further liberalisation as a result of EEC regulations having been transformed into German law and, on the other, it had first to prepare the ground for further developments arising from the licensing of private insurance companies in the GDR; this was because insurance companies having their head offices or branches in the territory to which the law applied hitherto and wanting to take up business activity in the GDR required a lincence since this constituted an "extension of the area of operational sector or another sector in the area of validity" (Art. 13, paragraphs 1 and $226 \mathrm{VAG}$ ). The hcavily standardised applications were dealt with by the Supervisory Authority - whose job this was - in the shortest possible timc. Applications could be made equally by German insurance companies or by foreign ones established in the Federal Republic. The latter were required to submit other documents, however, as laid down in the EC law on cstablishment which has now become the law of the Federal

21 So Zschockelt, Fn. 13.

22 Vgl. Mudrack, Die Beaufsichtigung der Privatversicherung in der DDR, BB 1990 Nr. 26, Supplement Finanz-Berater S. 12.

${ }^{23}$ Anl. II zum (crsten) Staatsvertrag, Nr. II.8.1 Letzter Abs., Anl. V zum (ersten) Staatsvertrag, Nr. V. 2. Abs. 1.

${ }^{24}$ Staatsvertrag Anl. II Abschn. II Nr. 8, \$162 I Satz 2; Mudrack a.a.O. stellt die rechtstechnischen Schwicrigkeiten dar, die in der (kurzen) Zwischenzeit bis zum Wirksamwerden des Beitritts auch auf diesem Teilgebiet des Rechts zu überwinden waren.

2.5 BGBI II S. $518=$ VerBAV S. 385.

25. BGBI II 5.991.

26 Vgl. BAV in VerBAV 1990 S. 431. Auf Rechtszweifel, dic auf EG-Recht beruhen könnten, ist hicr nicht cinzugehen. 
Rcpublic. in particular the comments of the Supervisory Authority of the country of incorporation (Art. 110b, para. 3 and Art. 111, para. 2 VAG) ${ }^{27}$ The licensing documents were sent to the companies by the trade associations. At the moment, around 300 companics are licenscd to operatc in the GDR. Most of these have thcir head office in the Federal Republic, but there are also somc which have their hcadquarters in an EC member state and branches in Wcst Germany. Despite numerous reports of success, the practical business is evidently only just starting up. Non-EC insurance companies established in the Fcderal Republic can operatc without a licence provided they work "without intermidiaries", that is to say carrying out purcly service transactions. Insurers cstablished in other Member States can cover large and equivalcnt risks without requiring a licence. ${ }^{28}$ Companies authorised to cover risks from a branch in the Federal Republic cannot cover the classes of business for which they are licensed, as defined in the Annex to the Insurance Supervisory Law (VAG), on a servicc-transactions basis in the GDR (Art. 110d, para. 2, final part of sentence).

\section{Partial "dual-track nature" of Insurance Contract Law}

Because the Civil Code (ZBG) of the GDR was retained by the International Treaty. ${ }^{29}$ the General Conditions of Insurance used in the GDR must contain more favourable arrangements for the policyholder, especially with regard to delays in the payment of premiums (in accordance with Art. $250 \mathrm{ZBG}$ ), the charging of premiums pro rata temporis in cases where a contract is cancelled carly (Art. 262 ZBG), and in Casualty insurance for the legal consequences of breaches of duty on the part of the policyholder (causality requirement) (Art. $255 \mathrm{ZGB}$ ). Under one of the Annexes of the first International Treaty, these provisions remained in force for the GDR until 3rd October. ${ }^{30}$

When evaluating these and comparing them with the old GDR law, however, account should be taken of the fact that questions concerning the handling of contracts and the settlement of losses were determined administratively. and that civil actions were rare. In the legal area mentioned, a different law applied within Germany, and this continues for contracts concluded up to 3rd October 1990. With accession, parties to an insurance contract were able to choose the law of the Fedral Republic. Since 3rd October 1990 the West German VVG has applied unrestrictedly.

\section{Special conditions for the GDR}

Consequently, the Insurance Supervisory Authority saw itself obliged to formulate for the GDR, in cooperation with the insurance trade associations. Spccial Conditions which wcre incorporatcd into the blanket liccnsing procedurc in a standardised way, together with

27 Dazu Mudrack a.a. O. S. 17, der übrigens für die Zeit bis zum Wirksamwerden des Beitritts für EG-Unternehmen ohne Niederlassung in der Bundesrepublik keine Möglichkeit zur Begründung einer Nicderlassung in der DDR sah, weil das BAV insoweit mit der auf diesc erstreckten Kompetenz keine Aufsichtsbehörde eines Mitgliedstaates sei (S. 16). Mudrack sagt selbst, seine Bedenken seien wenig praktisch. weil es bis zum Beitritt schwerlich zu solchen Nicdcrlassungen kommen werdc. EG-politisch ist die Argumentation für nicht glïicklich zu haltcı.

28 VerBAV 1990 S. $275 \$ \$ 110 \mathrm{~g}$ and 111 VAG.

29 ZGB der DDR vom 19. 06. 1975 GBI. I S. 465.

$\because$ Anh. III Nr. II.8. 
the insurance companies' applications for extension of their operating sectors. These Special Conditions, to the extent that they have been agreed in concrete form, will apply until 31 Dec. 1991 and will takc precedence over any other General Conditions of Insurance. ${ }^{31}$ The companies had to submit for a series of classes and types of insurance "business-plan declarations" specifying their practice from the point of view of supervisory law. The Federal Cartel Office agreed to the introduction of standard regulations of this kind for a transitional period.

Where the Special Conditions do not relate to commercial risks, besides allowing for the aforementioned provisions, the Supcrvisory Authority obviously also wanted to take account of the GDR's interests by granting an applicant, amongst other things, a limited right of cancellation and, in the case of a contract period of at least one ycar, the right to give written notice of cancellation in each case one month prior to the end of the ycar of insurance, and also in cases of premium adjustments. 32

With these arrangements, which arc not prescribed in the law applicable in the Federal Republic, ideas on deregulation and liberalisation are complied with - bypassing, as it were, the cnacted law of the Federal Republic. As alrcady mentioned, after 3. 10. 1990 companies will also be able to arrange insurance on the basis of the relevant General Conditions of Insurance applying in the Federal Republic, but will still have to observe the Special Conditions for the right of cancellations up until 31. 12. 1991.

It also has to be mentioned that, shortly before its accession to the Federal Republic, the GDR, in provisions relating to the compulsory insurance of socialist enterprises in agriculture and of state-run bodies and institutions and nationally-owned sectors of the economy, in principle abolished the obligation to insure and stated that insurances would continue to apply at existing terms and rates up until 31.12 .1990 as voluntary insurances. ${ }^{33}$

\section{Comments on individual issues}

It is not easy to find solutions to practical individual issues because "both" legislators the Federal Republic's and the GDR's - were not working completely in tune with each other, especially in 1990, and also because the transitional provisions enacted in the GDR ${ }^{34}$

31 Sie sind für folgende Versicherungszwcige und -arten geschaffen worden: Lebensversicherung, Hausrat-, Wohngebäude- und Glasversicherung im Privatkundengeschäft, betriebliche/betriebsbezogene Sachversicherung, Allgemeine Haftpflichtversicherung, dazu auch DDR-Sonderbedingungen zur Privathaftpflichtversicherung, Allgemeine Unfallversicherung, Fahrzeug- und Kraftfahrt-Unfallversicherung and Rechtsschutz- und Verkehrs-Service-Versicherung. Schließlich gibt es derartige Sonderbedingungen für die nicht in die Transportversicherung cingerechnete langfristige Reisegepäckversicherung mit Nebenzweigen und die kurzfristige Reisegepäck- und die Reiscrücktrittskosten-sowie die Ausstellungs- und Automatenversicherung (VerBAV 1990 S. 275-283). Die Sonderbedingungen für die Kraftfahrt- und die Krankenversicherung sind noch nicht amtlich veröffentlicht worden.

32 Sonderbed. Leben; ebenso Sonderbed. Hausrat pp., Allgemeine Haftpflicht, Allgemeine Unfall, Fahrzeug- und Kraftfahr-Unfall, Rechtsschutz und Verkehrs-Service, langfristige Reisegepäck usw. (vgl. BAV 1990, 277).

33 VO über die Authebung von Rechtsvorschriften auf dem Gebiet des Versicherungswesens vom 28. 08.1990 .

${ }^{34}$ Hierunter fallen z. B. auch die Anordnungen des DDR-Finanzministers über die Aufhebung der Vorschriften auf dem Gebiet der freiwilligen Sach- und Haftpflichtversicherung, der freiwilligen Personenversicherungen, derjenigen der Kulturen von privaten Gartenbaubetricben pp. und derjenigen der Parteion und gesellschaftlichen Organisationen (alles GBI. der DDR 1990 l S. 1268 ff.). Zu den von den der DDR übernommenen Bundesgesetzen pp. vgl, den DDR-Report in Der Betrieb 1990 S. $3(094$. 
bevore the International Treaty came into effect created certain difficulties. These problems were largely eliminated with the entry into force of the Unification Treaty and also the opening of the door to EC law.

One of the many special features of the former insurance scene in the GDR which continue to have an effect is the fact that life assurance there was regarded as a special form of saving and that its function as provision for old age and for survivors was hardly seen. The capital investments in life assurance policies earned interest at a slightly higher rate and were therefore attractive. Ten-year contracts were preferred, with the result that life assurance policies there became a pure financing instrument. The 1896/1937 mortality table was in use there with an actuarial interest rate of $3 \%$, resulting in high transfers of profits to the state. The "savings fund" was deposited with the state bank, and the life insurer had no right of disposal of the capital. 35 The current annual growth potential of the private life assurance sector is assumend to be relatively high. There have also been reports of demand for one-stop financial services, especially the small and medium-sized businesses sector and private persons keen on building. Because the land register system needed, amongst other things, for the creation of mortgages is not intact in the former GDR, a system of "list guarantees" was created for the GDR which is of particular importance, especially for the capital investments of life insurers.

In the non-life insurance sector, which - disregarding the problems caused by the Special Conditions - at first sight looks as if it can continue to be run smoothly by West German insurers, some thought of course has to be given to the considerably higher premiums needed and also, especially as regards liability insurance, to pre-existing burdens. Because the State Insurance Institution did not set up any underwriting reserves - any more than it provided actuarial reserves in the life assurance sector - so when the Allianz acquired a majority holding in Deutsche Versicherung (the successor to the State Insurance Institution) there ended up being a public discussion on who would assume the pre-existing burden, which according to press reports was officially estimated at some DM 6 billion. The Allianz - according to press reports - ruled out the possibility of its assuming this burden, which therefore falls upon the government of the GDR. It is generally quite difficult to make an assessment for the liability sector too, on account of the very numerous expropriations of land which I have already mentioned. The Homeowners' insurance sector will have to contend with considerable acceptance and rating problems, as it has been estimated that up to $80 \%$ of the stock of old buildings in the former GDR are in such poor condition that they can hardly be insured according to conventional principles.

Similarly, because the Motor Liability sector - which has had to be "de-monopolised", though the obligatory nature of this insurance has been retained - was also bound up with the levying of motor vehicle tax, the changeover to the West German system, and thus to the basic system of the EC member states, required extensive legislative work. On top of this came urgently required changes in tariffs, which were also very important, as the dcgree of motorisation has increased dramatically since the fall of the communist regime,

35 Darüber G. Radtke, Zeitschrift für Versicherungswesen, 1990, S. 314; generell über Chancen und Risiken des Versicherungsmarktes der DDR in P. Bach (Hsg.), Entwicklung und Perspektiven des Versicherungswesens in der DDR, Karlsruhe 1990, S. 103; Bericht von Traub über ein Symposium in Ostberlin, Zeitschrift für Versicherungswesen 1990, S. 357; Lieserfeldt und Präve, VW 1990, S. 890 ff. und $896 \mathrm{ff}$. 
while the road conditions remain poor. Regulations have in the mcantime becn issued which at the same time makc the system of Motor Liability insurance operated there compatible with that of the EC. ${ }^{36}$

One intcresting aspect is the development of an insurance in respect of companies investment burdens. With this, firms which have bought a company or land on former GDR tcrritory, or have acquired the rights of use thereof, also rcccive rctroactive cover in respect of claims for restitution from formcr owncrs of the property. Whether and, if so, to what extent the GDR's enormous need to catch up in the arca of environmcntal protection will lead to special tasks for insurance still remains to be seen.

Sickness insurance on an individual basis was not available in the GDR. With the abolition of the state monopoly rights, it therefore perhaps seemed easicr to start from scratch in this scctor than would have been the case for other classes of business, which would have initially involved continuing with contracts established by the monopoly institution.

A large number of West German Health insurers will commence business on 1st January 1991, based provisionally and for a limited period on a jointly elaborated so-called "basic tariff" approved by the Supervisory Authority. However, it will first of all be necessary to wait for reform of the social insurance system, which will bring employees with monthly salaries in excess of DM 2,250 and also civil servants and self-employed persons exemptions allowing them to arrange private health insurance, and thus in principle make it possible to finance private-patient status. In this market sector too, insurers will first of all have to gain experience - as they will also need to do with medical, pharmaceutical and hospital costs.

Generally speaking, in the GDR there is an extraordinary lack of managerial and qualified insurance staff. The influx of West German staff will, however, lead on both sides to certain psychological and concrete difficulties, which are we sure to overcome for the most part in the months ahead.

${ }^{36}$ Praktisch wichtig ist die VO über die Pflichtversicherung für Kraftfahrzeughalter vom 01. 08. 1990 (GBI DDR I S. 1053). 